\title{
Systemic Economic Harm in Occupied Palestine and the Social Connections Model
}

\author{
Shahd Hammouri
}

\section{Contents}

I Introduction

II Identifying Systemic Economic Harm in Occupied Palestine
A Empirically Identifying Systemic Economic Harm in Occupied Palestine
B Normatively Identifying Systemic Economic Harm

III Alternative Paths of Redress for Systemic Economic Harm under Occupation

\author{
A Systemic Economic Harm and the Business and Human Rights \\ Framework \\ B Third States and Systemic Harm in Occupation \\ IV Concluding Remarks
}

\section{Introduction}

Legal imagination is predisposed to think of the world in terms of physicality, if one's property is stolen, a lawyer does not need creativity to write up the claim, but what of the rights of someone whose business has been damaged as a result of discriminatory economic policies? The effect of such impediments can be described under the notion of "systemic economic harm." In theory, all humans have the right to pursue their economic development. ${ }^{1}$ In practice, one's economic positioning is shaped by a set of predetermined conditions, prompted by a host of discourses, ${ }^{2}$ and affected by a number of actors includ-

\footnotetext{
1 See International Covenant on Economic, Social and Cultural Rights, Dec. 16, 1966, 993 U.N.T.S. 3 .

2 See Iris Marion Young, Responsibility for Justice 56-59 (2011) [hereinafter Young (2011)].
} 
ing states and corporations. ${ }^{3}$ Herein, one's capacity to pursue such development can be indirectly impeded by structural injustice engraved within a given normative system. In this respect, the international legal imagination, limited by needs of legality and coherence, cannot fully integrate all structural and contextual considerations. Yet, it is in contexts of heightened precarity caused by direct acts of domination such as a prolonged occupation, where the disparities caused by the absence of structural thought call for a more nuanced approach. ${ }^{4}$

This present article tackles the context of the Israeli occupation of Palestine to ask whether the existing framework of international law applied in situations of occupation captures and adequately addresses situations of systemic economic harm. Acknowledging the limitations of international law, it ventures to explore the remedial potentialities of different frameworks which escape traditional limitations of national legal systems. How is responsibility for systemic economic harm imagined? What are the avenues of redress available to address systemic economic harm in situations of occupation? Part one attempts to empirically and normatively identify such systemic economic harm. The second part investigates possible remedial paths for such systemic economic harm via international responsibility mechanisms for corporate actors involved in the occupation's economic apparatus, as well as states interacting with it.

This article is premised on the theoretical claim that remedying such injustice requires a holistic perception of causality to trace the connections sustaining dire economic conditions. In effect, it argues that the rare presence of such structural thinking in international law renders it inadequate to address systemic economic harm impeding on the right of the occupied population to pursue economic development. In one respect, the call for the integration of structural perspectives within the optic of international law bears the risk of increased indeterminacy. ${ }^{5}$ In another respect, accepting this absence sets low expectations for international law and deepens the insecurities caused by its

3 According to Iris Marion Young, structural injustice entails a duty on different actors to remedy the systems that sustain such structural harm, including legal persons such as corporate actors and states. $I d$., at 144-150.

4 Structural injustice exists, according to Iris Marion Young, when "social processes put large categories of persons under a systematic threat of domination or deprivation of the means to develop and exercise their capacities." Id., at 143 .

5 "As soon as the law tries to make an assessment about the larger interest, and evaluate the relevant contextual data, it will move on to an area of indeterminacy and political conflict." Martti Koskenniemi, Between Impunity and Show Trials, 6 Max Planck Y.B. U.N. L. 1, $29(2002)$. 
claim for some form of international prosperity. Furthermore, as shown below, the absence of structural thinking serves to deepen the disadvantages of international law's "others." This appeal to structural thinking has gained further prominence in international legal literature over the past few years, with works of authors such as Zinaida Miller, ${ }^{6}$ Larissa van den Herik, ${ }^{7}$ John Linarelli, Margot E. Salomon, Muthucumaraswamy Sornarajah, ${ }^{8}$ among others.

To evaluate the capacity of international law to address systemic economic harm, this paper relies on Young's account of the "social connections model." This model provides a critical account geared towards capturing indirect causality in globalized systems. ${ }^{9}$ To introduce this perspective, prior reference to John Glatung's work is warranted. Glatung gives a broad understanding of violence, as the cause of difference between a potential state of affairs and the actual state of affairs. ${ }^{10}$ For example, if $A$ had the potential and initial capacity to go to school, but the occupation forces built a settlement on the road leading to the school, then A's access to school is limited. ${ }^{11}$ The difference between his initial potential, and the actuality of limited access, is a form a violence from Galtung's perspective. Such violence comes in many different forms: direct

6 Despite her focus on transnational justice, the work of Zinaida Miller provides crucial insights for the general cohort of international law. "The literature, institutions and international enterprise of transnational justice have historically failed to recognize the full importance of structural violence, inequality and economic distribution in conflict...." Zinaida Miller, Effects of Invisibility: In Search of the "Economic" in Transitional Justice, 2 Int' J. Trans. J. 266, 267 (2008).

7 "The current justice processes offer only a one-dimensional narrative that is focused on physical violence, and in which economic structural root causes remain invisible." Larissa van den Herik, Economic, Social, and Cultural Rights - International Criminal Law's Blind Spot? in Economic, Social, and Cultural Rights in International Law 343, 365 (Eibe Riedel, Gilles Giacca, and Christophe Golay eds., 2014).

8 See, e.g., discussion of structural vulnerabilities in: John Linarelli, Margot E. Saloman, and Muthucumaraswamy Sornarajah, The Misery of International Law: Confrontations with Injustice in the Global Economy 6o-63 (1st ed., 2018).

9 See, e.g., Catherine Larrère, Responsibility in a Global Context: Climate Change, Complexity, and the "Social Connection Model of Responsibility", 49 J. Soc. Phil. 426 (2018); Harry J. Van Buren, Judith Schrempf-Stirling, \& Michelle Westermann-Behaylo, Business and Human Trafficking: A Social Connection and Political Responsibility Model, 6o Bus. \& Soc'y 341-375 (2021).

10 See Johan Galtung, Violence, Peace, and Peace Research, 6 J. Peace Res. 167, 168 (2016) [hereinafter Galtung].

11 This example relies on real events, under which access is schools is impeded by the policies of the Israeli occupation. See Commission of the Churches on International Affairs, World Council of Churches, Education under Occupation: Access to Education in the occupied Palestinian territory (2013), https://www.unicef.org/oPt/UNICEF_Under_ Occupation_final-SMALL.pdf. 
and indirect, physical and psychological, intended and unintended. ${ }^{12}$ Some forms of violence are not traceable to a specific person. Rather, they are the effect of structures that sustain uneven the distribution of resources. ${ }^{13}$ As this paper will show, in the occupation context, such structures are often the result of international law violations. The harm inflicted by such structures is less apparent given that they manifest over an extended period of time. ${ }^{14}$ This article applies this general understanding of violence to a specific form of it: the indirect violence of occupation policies that cause systemic economic harm.

The proliferation of indirect forms of violence among members of a given community often indicates structural injustice. Structural injustice is often experienced on a collective level. Such a collective group can include, for example, economically less privileged classes in a given state, indigenous people, or people under the occupation. To this end, Young finds that structural injustice "exists when social processes put large groups of persons under systemic threat of domination or deprivation of the means to develop and exercise their capacities - at the same time that these processes enable others to dominate or have a wide range of opportunities for developing and exercising capacities available to them."15 Therefore, domination and deprivation are constitutive elements in the processes sustaining structural injustice. In this light, Young finds that the Palestinian peoples' right of self-determination can be conceptualized as the right of non-domination. ${ }^{16}$

In response to structural injustice, the social connections model suggests that all actors who contribute to the structural processes that produce injustice have a responsibility to work to remedy these injustices. ${ }^{17}$ Responsibility in this context is understood expansively as a duty to evaluate one's positioning towards the collective. Accordingly, all agents who take part in the connections establishing structural injustice have to take a critical stance to assess their position and take action to redress such harm within their capacities.

Young's formula identifies the elements which shape an agent's responsibility towards a given structural injustice, which include: (1) the agent's positioning of power towards the given injustice, that is often accompanied by a level of privilege that indicates a capacity to undertake action against such structural

See Galtung, at 169-173.

See id., at 170,175 .

See id., at 174 .

Young (2011), at 52 .

See Iris Marion Young, Self-determination as non-domination: Ideals applied to Palestine/ Israel, 5 Ethnicities 139, 140 (2005).

17 See Iris Marion Young, Responsibility and Global Justice: A Social Connections Model, 23 Soc. Phil. \& Pol'y 102, 103 (2006). 
causes; ${ }^{18}(2)$ the agent's interest in eradicating a given structural injustice, such interest is often that of the subject affected by the structural injustice (with this element, Young's perspective endows an obligation on those affected by the injustice to contest the structure); 19 and, lastly, (3) "collective ability" to undertake action. ${ }^{20}$

Indeed, in practice such elements entrap the subjugated in a paradoxical situation, as those with power and privilege often lack any interest in changing the structure, and those whose are interested in change it rarely have the capacity to do so. ${ }^{21}$ Thus far, Israel has not exhibited any will to change the structure sustaining systemic economic harm inflicted upon Palestinians. Consequently, Palestinians are left in a space where their legal and political capacity to contest the structure is stripped to the bare minimum. While Young's model is not intended to be legal, her thinking can serve to guide alternative approaches to harnessing remedies for systemic harm caused by the Israeli occupation.

The context of occupation is apt for such an investigation into structural justice as the infliction of indirect harm is somewhat spatially defined within the parameters where the policies of the occupation apply (this is especially true in the case of settlements). More so, such indirect violence is also inflicted on account of one's legal status as a Palestinian. These parameters limit the scope of assessment for structural injustice paving the way for legal scrutiny. Secondly, international law has a role to play in the normalization of the general apparatus of occupation as an exceptional act of domination under the 1907 Hague Regulations. ${ }^{22}$ Thirdly, the prolongation of the occupation has allowed for the normalization of systems designed in the spirit of occupation.

Concurrently, the context of occupation is ripe for the proliferation of systemic harm as it facilitates the possibility of exploitation and depravation in a defined temporal and spatial framework. It is for this reason that its temporary nature has been repeatedly stressed, ${ }^{23}$ especially with relevance to the context of the Israeli occupation of Palestine. ${ }^{24}$ These factors come together to shape the precariousness of the Palestinian population to severe economic impoverishment under a direct act of domination discussed in the following part.

\footnotetext{
18 See Young (2011), at 144-145.

19 See id., $145^{-146 .}$

20 See id., at 147.

21 See id., at 148.

22 See Chris af Jochnick \& Roger Normand, The Legitimation of Violence: A Critical History of the Laws of War, 35 Harv. Int'l. L. J. 49 (1994).

23 See Commentary on the Geneva Conventions of 12 August 1949: IV Geneva Convention relative to the Protection of Civilian Persons in Time of War 275 (Jean S. Pictet ed., 1958); Iain Scobbie, International Law and the Prolonged Occupation of Palestine (2015), https:// papers.ssrn.com/abstract=2611130.

Omar M. Dajani, Israel's Creeping Annexation, 111 AJIL Unbound 51-56 (2017).
} 


\section{Identifying Systemic Economic Harm in Occupied Palestine}

This part substantively identifies systemic harm and its causality in the context of occupation. To do so, it is divided into two sections. The first section sets out to empirically identify forms of systemic harm in occupied Palestine in relation to international law violations, whereas the second section addresses the theoretical legal issues which arise when we attempt to imagine systemic harm through the international law lens.

\section{A Empirically Identifying Systemic Economic Harm in Occupied Palestine}

Systematic and repeated international law violations generate domination and deprivation causing structural injustice. In this respect, the Israeli occupation is accompanied by a number of blanket violations which breed systemic economic harm - such as the violation of the Palestinian right to self-determination, ${ }^{25}$ and the installment of a discriminatory regime of governance that many deem as a form of apartheid. ${ }^{26}$ That is in addition to a host of blanket violations which are more spatially defined such as the settlements, ${ }^{27}$ and the blockade on Gaza. ${ }^{28}$ This section illustrates the interrelation between the accumulation of international humanitarian law violations including the law of occupation an the dire conditions of the Palestinian economy.

In 2016, the United Nations (UN) Conference for Trade and Development (UNCTAD) submitted a report to the UN General Assembly, drawing a link

25 See Legal Consequences of the Construction of a Wall in the Occupied Palestinian Territory, Advisory Opinion, 2004 I.C.J. Rep. 136 (July 9), paras. 115, 118, 122; Susan Hattis Rolef, The Palestinians' Right to Self-Determination, 16 J. Palestine stud. 17 (1987).

26 See John Dugard, Implementation of General Assembly Resolution 60/251 of March 2006 entitled 'Human Rights Council', Report of the Special Rapporteur on the situation of human rights in the Palestinian territories occupied since 1967, John Dugard, U.N. Doc. A/HRC/4/17 (Jan. 29, 2007), paras. 49-5o. See also Ilan Pappé, Israel and South Africa: The Many Faces of Apartheid (2015); Uri Davis, Israel: An Apartheid State (1987); Michael Sfard, The Israeli Occupation of the West Bank and the Crime of Apartheid: Legal Opinion, Yesh Din (June 202O), https://s3-eu-west-1.amazonaws.com/files.yesh-din.org/Apartheid+2O2O/ Apartheid+ENG.pdf; B'Tselem, A regime of Jewish supremacy from the Jordan River to the Mediterranean Sea: This is apartheid (Jan. 2021), https://www.btselem.org/publications/ fulltext/202101_this_is_apartheid; Nathan Thrall, The Separate Regimes Delusion, 43 London Rev. Books (Ja. 21, 2021), https://www.lrb.co.uk/the-paper/v43/no2/nathan-thrall/ the-separate-regimes-delusion.

27 See, generally, Simon McKenzie, Disputed Territories and International Criminal Law: Israeli Settlements and the International Criminal Court (2019).

28 See, generally, Marty Gitlin, The Blockade of the Gaza Strip (2019) [hereinafter Gitlin]. 
between the institutional policies of the Israeli occupation and the deterioration of the Palestinian economy. ${ }^{29}$ It also drew a link between such economic deterioration and systemic forms of suffering imposed upon the Palestinian people. ${ }^{30}$ Overall, the report illustrates how the policies of the Israeli occupation have been a main factor in the economic impoverishment of the Palestinian people. This claim is exemplified in the following observations: had the trends of growth observed prior to the occupation in 1967 continued, the real Gross Domestic Product in Palestine would have been 88\% higher. ${ }^{31}$ Thus, the occupation has drastically stymied Palestinian economic growth. Likewise, it is also estimated that the Palestinian economy suffered a $\$ 48$ billion revenue loss between $2000-2017$ as a result of the occupation. ${ }^{32}$ As such, the general context of prolonged occupation causes systemic harm to the Palestinian economy on a macro-level. This comes in tandem to the micro-level economic harm that different Israeli institutional structures and policies cause, especially in the agricultural and industrial sectors where the policies of land confiscation result in a systemic loss of grazing and agricultural land. ${ }^{33}$

Overall, the occupation has obstructed the development of the Palestinian economy. In one respect, Israeli policies impede Palestinians' productive and commercial capacities and make competition on global markets for goods and services nearly impossible. ${ }^{34}$ In another respect, Israeli control over the regulation of investment creates uncertainty and thus deters foreign investment in Palestine. ${ }^{35}$

29 See Raja Khalidi \& Sahar Taghdisi-Rad, The economic dimensions of prolonged occupation: Continuity and change in Israeli policy towards the Palestinian economy: A special report commemorating twenty-five years of UNCTAD's programme of assistance to the Palestinian people, UNCTAD (Aug. 2008), https://unctad.org/system/files/official-document/ gds2oog2_en.pdf.

30 UNCTAD, Economic costs of the Israeli occupation for the Palestinian people, U.N. Doc. A/71/174 (July 21, 2016), para. 18 [hereinafter UNCTAD (2016)].

$31 \quad$ Id., para. 17.

$32 \$ 48$ billion is the estimated revenue loss by Palestine from 2000-2017 due to occupation, UNCTAD (Dec. 2, 2019), https://unctad.org/en/pages/newsdetails.aspx?Original VersionID=2254.

33 See id., para. 16. See also Yehezkel Lein, Land Grab: Israel's Settlement Policy in the West Bank, B'Tselem (May 2002), https://www.btselem.org/publications/summaries/ 200205_land_grab; Nir Shalev, Under the Guise of Legality: Israel's Declarations of state land in the West Bank, B'Tselem (Mar. 2012), https://www.btselem.org/publications/ summaries/201203_under_the_guise_of_legality.

34 See Peter Lagerquist, Privatizing the Occupation: The Political Economy of an Oslo Development Project, 32 J. Palestine Stud. 5 (2003) [hereinafter Lagerquist]; UNCTAD (2016), n26.

See, generally, Lagerquist; UNCTAD (2016). 
In the interim, economic agreements such as the Oslo Accords and the Paris Protocol (which were devised to organize economic relations between Israel and Palestine) are deeply defined by the asymmetrical and dominating reality of the occupation. ${ }^{36}$ As Mohammad Samhouri illustrates, such agreements provide very minimal support for the Palestinian economy, which requires independence as a primary precondition for growth. ${ }^{37}$

The spill over of the asymmetrical nature of this economic relationship is also evidenced in how projects undertaken under the banner of "development" often lack good faith in operation. Peter Lagerquist illustrates this point in his study of one of the Oslo-affiliated development projects in the 1990s. This project included the construction of a series of industrial zones in the West Bank and the Gaza border with Israel and received funding from multiple international financial institutions. Lagerquist showcases how the project's design alienated Palestinian investors and worked as a space to direct excess foreign investment from Israel in pursuit of cheap operation costs. ${ }^{38}$ Eventually, programs designed under the banner of development often supplement Israeli exploitation. ${ }^{39}$

This exploitation is also evident in the context of rules of usufruct. ${ }^{40}$ As an occupying power, Israel has a duty to administer the resources of the occupied territories within the rules of usufruct under the Hague Regulations (which are distinct in their reference to private property and discussion of economic considerations, not found elsewhere in the body of the laws of war). There are different interpretations as to the rules governing the boundaries of the standard of usufruct. Yet, as a general rule of thumb, Jessup notes, the occupant's actions ought to have a solid basis in law, and its acts ought to be "in good faith for the management of the community under war conditions and not for his [i.e. the occupant's] own enrichment." ${ }^{11}$

${ }_{3} 6$ See Raja Khalidi, The Structural Transformation of the Palestinian Economy after Oslo, in From the River to the Sea: Palestine and Israel in the Shadow of Peace 95 (Mandy Turner ed., 2019).

See Mohammed Samhouri, Revisiting the Paris Protocol: Israeli-Palestinian Economic Relations, 1994-2014, 70 Middle East J. 579 (2016).

38 See Lagerquist.

39 See id.

40 Usufruct is defined as: "The right of reaping the fruits (fructus) of things belonging to others, without destroying or wasting the subject over which such rights extend." Jonathan Law, Usufruct, Oxford Dictionary of Law (9th ed., 2018). Hague Convention IV - Laws and Customs of War on Land art. 55, Oct. 18, 1907, 3 Martens Nouveau Recueil (ser. 3) 461 [hereinafter Hague Regulations].

41 Philip C. Jessup, A Belligerent Occupant's Power over Property, 38 Am. J. Int'l L. 457, $45^{8}$ (1944). 
Against the backdrop of this standard, one should assess Israeli policies for administering water resources and quarries. UNCTAD notes that "By 2004, more than 85 per cent of Palestinian water from West Bank aquifers had been taken by Israel, covering 25.3 per cent of Israel's water needs." ${ }^{42}$ Such policies contravene Appendix I and Annex III of the Israeli-Palestinian Interim Agreement on the West Bank and the Gaza Strip (1995). ${ }^{43}$ This policy exemplifies systemic depravation, which eventually leads Palestinians to depend on Israeli water imports, or resorting to unsafe water resources. ${ }^{44}$ Such policies effectively violate the right to safe and clean water. ${ }^{45}$ Mark Zeitoun describes Israeli water extraction policies under the term hydro-hegemony. ${ }^{46}$ Zeitoun finds that "Israeli control over transboundary fresh water is complete at many levels," 47 and that water deprivation in Palestine "is the result of extremely varied but systematic endeavours by one of the parties to perpetuate and extended their superiority over the other." 48

The violation of the rules of usufruct is also evident in the case of quarries. Israeli and multinational corporations have been actively investing in the quarrying business in the West Bank for the benefit of Israel since the 1970s. ${ }^{49}$ Quarrying in the West Bank requires cheap Palestinian labor, and the externalization of the environmental effects of quarrying to Palestinian territories. From an economic perspective, such activities provide minimal economic gain for Palestinians in return for the exploitation of their natural resources. Ultimately, the exploitation of the occupied population's natural resources

42 UNCTAD, The Economic Costs of the Israeli Occupation for the Palestinian People: The Unrealized Oil and Natural Gas Potential, UNCTAD/GDS/APP/2019/1 (2019), at 8 [hereinafter UNCTAD (2019)].

43 See H.R.C., Israeli settlements in the Occupied Palestinian Territory, including East Jerusalem, and in the occupied Syrian Golan, U.N. Doc. A/HRC/34/39 (Apr. 13, 2017), para. 11; UNCTAD (2019), at 8-12.

44 U.N. Doc. A/HRC/34/39 (2017), para. 16 (which notes that Palestinians have lost $82 \%$ of their water resources due to the occupation).

45 See The human right to water and sanitation, U.N. Doc. A/RES/64/292 (July 28, 2010).

46 See Mark Zeitoun, Power and Water in the Middle East: The Hidden Politics of the Palestinian-Israeli Water Conflict 145-155 (2012).

47 See id., at 49.

48 Id., at 146-147.

49 See Maha Abdallah \& Lydia De Leeuw, Violations Set in Stone: HeidelbergCement in the Occupied Palestinian Territory, Al Haq \& SOMO (Feb. 2020), http://www.alhaq.org/ publications/16408.html; B'Tselem, High Court sanctions looting: Israeli quarries in the West Bank (Jan. 2012), https://www.btselem.org/settlements/20120116_hcj_ruling_on _quarries_in_wb. 
is undertaken for the sole enrichment of Israel, in contravention the rules of usufruct. ${ }^{50}$

Taxation policies further exemplify the systemic harm that the Israeli occupation inflicts on Palestinians under its control. Hague Regulations article 48 stipulates that the occupier ought to abide as far as possible with existing taxation regimes when it regulates tax in an occupied territory, and that tax proceeds are to be paid to facilitate the administration of the occupied territory. Article 49 prohibits the collection of further levies unless justified for military purposes or required for the administration of the occupied area. In reality, the occupying power imposes differential tax regimes that place a heavier burden on Palestinians engaged in economic activities, whether in Palestine or in Israel, and that mark a deep asymmetry in the economic relations between the two parties. ${ }^{51}$ Selective taxing policies deepen the market disadvantage of Palestinian goods and services competing with Israeli products. ${ }^{52}$ Similarly, the occupation's tax regime incites systemic transfer of resources that is not supplemented by investment in the Palestinian public sector. For example, the taxes that Palestinian workers in Israel pay go directly to Israel, but Israel does not dispense expenditures on public services to Palestinians. ${ }^{53}$ Overall, "the total of these resource transfers is large and, according to some estimates, exceeds in any given year 15 per cent of the Palestinian GDP."54

$5^{\circ} \quad$ See Yesh Din, The Great Drain: Israeli quarries in the West Bank: High Court Sanctioned Institutionalized Theft (Sep. 2017), https://www.yesh-din.org/en/great-drain-israeli -quarries-west-bank-high-court-sanctioned-institutionalized-theft/; Valentina Azarova, Exploiting A 'Dynamic' Interpretation? The Israeli High Court of Justice Accepts the Legality of Israel's Quarrying Activities in the Occupied Palestinian Territory, EJIL: Talk! (Feb. 7, 2012), https://www.ejiltalk.org/exploiting-a-dynamic-interpretation-the -israeli-high-court-of-justice-accepts-the-legality-of-israels-quarrying-activities-in-the -occupied-palestinian-territory/.

51 In agriculture, systems of land tax as derived from the commutation of the old Ottoman tithe and imposed on Palestinian farmers have placed a disproportional tax burden on them. In manufacture, Palestinian manufactures pay $35^{-40} \%$ more tax than their Israeli counterparts, eventually leading to the reality where almost no capital market exists in the occupied territories as cash flows are drained by higher taxes or invested back in the building of family dwellings or placed in liquid funds in Jordanian dinars. See The Palestinian Economy: Studies in Development under Prolonged Occupation 68 (George T. Abed ed., 1988) [hereinafter Abed]; Roger Owen, Economic Development in Mandatory Palestine: 1918-1948, in Abed; Raja Khalidi, The Economy of Palestinian Arabs in Israel, in Abed.

$52 \quad I d$.

53 See UNCTAD (2016), at 10.

54 See UNCTAD (2019), at 10. 
Likewise, the establishment and maintenance of settlements is a spatially limited form of a violation that breeds systemic economic harm on a given collective of people. In the settlements, the spatial context of the economic activity itself is illegal, as the establishment of settlements violates the prohibition against displacing the civilian population, ${ }^{55}$ and the prohibition against confiscating land in occupied territories (except in specific circumstances). ${ }^{56}$ The continuation of this illegality fosters a host of systematic human right violations, ${ }^{57}$ the effect of which proliferates with the occupation's exploitative and discriminatory economic policies. For example, Israeli settlements disproportionally drain the water resources shared with Palestinians. ${ }^{58}$ Likewise, the infrastructure networks which were built to serve settlements cross through Palestinian lands, denying Palestinians proper access to roads. ${ }^{59}$ Moreover, the geographical choices of settlement building hinder existing commercial communication lines contributing to the segmentation of Palestinian economies. ${ }^{60}$

The act of displacement in and of itself impacts the population's economic capacity. It displaces their sources of livelihoods, ${ }^{61}$ denies their property rights, impedes their access to natural resources, and eventually forces Palestinians to accept low wage, low-skill manual labor. This results in a labor flow that redistributes the economic yield of such productive capacities from the Palestinian economy to the Israeli economy. It thus provides a considerable source of financing for imports on the Israeli side. ${ }^{62}$

55 Geneva Convention (IV) Relative to the Protection of Civilian Persons in Time of War art. 49(6), Aug. 12, 1949, 75 U.N.T.S. 287 [hereinafter Fourth Geneva Convention]; Protocol Additional to the Geneva Conventions of 12 August 1949, and relating to the Protection of Victims of International Armed Conflicts art. 85(4)(a), June 8, 1977, 1125 U.N.T.S. 3.

56 See ICRC, Rule 51. Public and Private Property in Occupied Territory, IHL Database: Customary IHL, https://ihl-databases.icrc.org/customary-ihl/eng/docs/v1_rul_rule51; Ghazi Falah, Dynamics and patterns of the shrinking of Arab lands in Palestine, 22 Pol. Geography 179 (2003); Land Confiscation 6 J. Palestine Stud. 153 (1976).

57 See Human Rights Watch, Occupation, Inc: How Settlement Businesses Contribute to Israel's Violations of Palestinian Rights (Jan. 2016), https://www.hrw.org/news/2016/o1/19/ occupation-inc-how-settlement-businesses-contribute-israels-violations-palestinian.

$5^{8}$ See, generally, Abed.

59 Id. See also Samira Shah, On the road to apartheid: the bypass road network in the West Bank, 29 Columbia Hum. Rts. L. Rev. 221 (1997); B'Tselem, Forbidden Roads Israel's Discriminatory Road Regime in the West Bank (Aug. 2004), https://www.btselem.org/ publications/summaries/200408_forbidden_roads.

6o See, generally, Abed.

61 Alex Pollock Society and Change in the Northern Jordan Valley, in Abed.

62 UNCTAD (2016), para. 13. 
Finally, acute forms of systemic economic harm have manifested in Gaza, in part as consequence of the siege. Israel has imposed considerable restrictions on movement in the Gaza Strip since the 199os citing security concerns. Following Hamas' victory in the internationally monitored elections for the Palestinian authority in 2007, Israel imposed a more severe form of blockade on land, air, and sea unto the territory of the Gaza Strip. ${ }^{63}$ The practice of blockade is itself illegal, ${ }^{64}$ and a form of collective punishment, ${ }^{65}$ that "is being imposed to apply pressure to the de facto authorities, and in response to acts committed by various groups in Gaza." ${ }^{\text {6 }}$ Such a form of punishment is prohibited under Fourth Geneva Convention article 33 and Hague Regulations article $50^{67}$

The effects of such collective punishment are crippling. Gaza has one of the highest rates of unemployment worldwide due to the limitations on the growth of its economy. ${ }^{68}$ Movement restrictions impede its capacity to undertake commercial activities with the rest of the world, especially given the Israeli imposition of quotas on imports and limitations on fishing activities. ${ }^{69}$

63 See Gitlin; U.N. OCHA, Occupied Palestinian Territory, Glaza Blockade, https://www .ochaopt.org/theme/gaza-blockade.

64 See Russell Buchan, II. The Palmer Report and the Legality of Israel's Naval Blockade of Gaza, 61 Int'l \& Comp. L. Q. 264 (2012).

65 See H.R.C., Implementation of Human Rights Council Resolutions $S-9 / 1$ and $S-12 / 1$, U.N. Doc. A/HRC/34/36 (Jan. 25, 2017), para. 36 .

66 H.R.C., Human rights situation in the Occupied Palestinian Territory, including East Jerusalem, U.N. Doc. A/HRC/24/30 (Aug. 22, 2013), para. 22.

67 "No protected person may be punished for any offense he or she has not personally committed. Collective penalties and likewise all measures of intimidation or of terrorism are prohibited." Fourth Geneva Convention art. 33. "No general penalty, pecuniary or otherwise, shall be inflicted upon the population on account of the acts of individuals for which they cannot be regarded as jointly and severally responsible" Hague Regulations art. 5o. See also Amnesty International UK, Gaza Blockade: 'collective punishment' condemned, Press Release (Jan. 21, 2008), https://www.amnesty.org.uk/press-releases/gaz a-blockade-collective-punishment-condemned; ICRC, Gaza closure: Not another year!, Press Release (June 14, 2010), https://www.icrc.org/en/doc/resources/documents/ update/palestine-update-140610.htm ("The whole of Gaza's civilian population is being punished for acts for which they bear no responsibility. The closure therefore constitutes a collective punishment imposed in clear violation of Israel's obligations under international humanitarian law.").

68 At the time of the research unemployment rates in Gaza stood at 49.1\%. Relief Web, Gaza unemployment rate in the second quarter of 2020:49.1\%, Press Release (Sep. 21, 2020) https://reliefweb.int/report/occupied-palestinian-territory/gaza-unemployment-rate -second-quarter-2020-491.

69 See, generally, UNCTAD (2016). 
The Gazans suffer from these restrictions on a daily basis, as they manifest in wide-range limitations including on housing, ${ }^{70}$ healthcare, ${ }^{71}$ food security, ${ }^{72}$ basic needs (such as water and electricity), ${ }^{73}$ and education. ${ }^{74}$ Consequently, they feed into the de-development of Gaza. ${ }^{75}$

To sum up, the accumulation of international law violations in the context of occupation has resulted in an overall apparatus of domination that creates a gross asymmetry in economic relations between the two sides. Overtime, such relations have resulted in systemic economic harm for the Palestinian people. The relation between such harm and violations of international law is apparent, and yet it seems difficult to articulate such harm from the or t: of international law.

\section{B Normatively Identifying Systemic Economic Harm}

In theory, the aforementioned violations are "wrongful acts" which give rise to Israeli responsibility for the harms they cause. According to the International Law Commission's draft articles on Responsibility of States for Internationally Wrongful Acts (ARISWA), "every internationally wrongful act of a state entails the international responsibility of that state." ${ }^{\prime 6}$ An internationally wrongful act is identified as "a breach of an international obligation of the state,"77 especially "an obligation arising under a preemptory norm of general international law,"78 that is attributable to the state. A breach of peremptory norms is identified as a "serious breach" which substantively includes the prohibition

70 See Norwegian Refugee Council, Overview of the Housing Situation in the Gaza Strip (Mar. 2013), at 45, 51-52.

71 SeeU.N.OHCHR,UNexpertssay Gazahealthcareat “breaking point”(June 21, 2018), https:// www.ohchr.org/en/NewsEvents/Pages/DisplayNews.aspx?NewsID=23236\&LangID=E.

72 See U.N. OCHA, Occupied Palestinian Territory, Food insecurity in the oPt: 1.3 million Palestinians in the Gaza strip are food insecure (Dec. 14, 2018), https://www.ochaopt.org/ content/food-insecurity-opt-13-million-palestinians-gaza-strip-are-food-insecure.

73 See U.N. Doc. A/HRC/24/30, paras. 10-23.

74 See U.N. OCHA, Occupied Palestinian Territory, Education, https://www.ochaopt.org/ theme/education.

75 See Sara M. Roy, The Gaza Strip: The Political Economy of De-development 135 (1995). Such policies have also be described as "institutionalized impoverishment;" see Trude Strand, Tightening the Noose: The Institutionalized Impoverishment of Gaza, 2005-2010, 43 J. Palestine Stud. 6, 17 (2014) 17.

76 U.N. I.L.C., Draft Articles on Responsibility of States for Internationally Wrongful Acts, with commentaries, in Report of the International Law Commission on the Work of Its Fifty-third Session, U.N. Doc. A/56/10 (2001), art. 1 [hereinafter ARSIWA, with commentaries].

$77 \quad$ Id., art. 2 (b).

78 Id., art. 40 . 
against apartheid and violations of the peoples' right to self-determination. ${ }^{79}$ Meanwhile, such seriousness is further escalated if it is "a gross or systematic failure by the responsible state to fulfil the obligation in question." 80 As such, Israel would be responsible for wrongful acts committed by its representatives in terms of administration in contravention of the rules of usufruct, prohibition against the forceful transfer of civilians, prohibition against collective punishment, and violation of bilateral economic agreements (among others).

However, the question remains as to how one should understand the harm such violations cause for the purpose of providing for a legal remedy. The attempts to articulate systemic economic harm in international law faces two sets of hurdles ingrained within normative structures for international responsibility.

Firstly, traditional liability models are focused on conduct rather than on effect. ${ }^{81}$ Accordingly, ARISWA is concerned with the violation rather than the harm caused. ${ }^{82}$ In addition, the substantive body of international law does not explicitly find occupation as a violation of the state's responsibility under international law. ${ }^{83}$ Therein, international law invites an assessment of the violation in a separate light th the harm caused. This approach entails accepting the risk of underrepre -...ing the systemic nature of the harm resulting from wrongdoing in occupation. Secondly, even if we are to assess the harm that the occupation causes outside of the ARISWA, structural economic harm is often hard to capture under a traditional liability model, as the causality is often seen as too indirect. There are three theoretical premises that underpin this shortcoming that originate in liberal political thought and foreground international legal thinking about responsibility:

- (1) The prominence of methodological individualism in contemporary legal thought. ${ }^{84}$ Captured in the work of Weber, this methodological choice calls for the conceptualization of causality and responsibility in terms of direct

79 See id., art. 40, at 112-113.

$80 \quad$ Id., at 113 .

81 See Andrew Nollkaemper \& Dov Jacobs, Shared Responsibility in International Law: A Conceptual Framework, 34 Mich. J. Int'l L. 359, 396 (2013).

82 See James D. Fry, Attribution of Responsibility, in Principles of Shared Responsibility, in International Law: An Appraisal of the State of the Art 98, 101-2 (André Nollkaemper \& Ilias Plakokefalos eds., 2014).

83 Hague Regulations art. 43 refers to the authority of the occupying power as legitimate. In this sense, a legitimate by-product of armed conflict. See Eyal Benvenisti, The International Law of Occupation 39-40 (2nd ed., 2012).

84 "The Liberal vision of law and economics idealizes individual independent agency as the essence of responsible power." Martha T. McCluskey, Personal Responsibility for Systemic Inequality, in Research Handbook on Political Economy and the Law 228, 238 (Ugo Mattei \& John D. Haskell eds., 2015). Galtung also notes that traditional thinking is focused 
relations among the actions of agents. ${ }^{85}$ Accordingly, legal liability systems consider injustice to arise in the course of relations among individuals, with minimal reference to how social structures shape a given outcome. ${ }^{86}$ As such, traditional thinking about accountability rests on facts primarily relevant to direct interpersonal relations. This thinking reflects what Kutz terms an "evaluative solipsism" that inadequately assesses collective and systemic forms of harm. ${ }^{87}$

- (2) Methodological nationalism, which is the tendency to frame societal issues within the national-territorial confines of the nation-state. ${ }^{88}$ It thus overlooks the interconnected and cross-border nature of causality chains (in particular the role of other states and private actors) in the causality chains for the purpose of the assessment of systemic economic harm.

- (3) The private-public distinction, found in the theoretical premises of international law, renders economic considerations outside public international law's assessment. ${ }^{89}$ As a result, economic realities resulting from economic competition and free enterprise are discussed only with reference to regimes of economic law, alienating relevant public international considerations. ${ }^{90}$ For example, there are ongoing scholarly disputes on international investment law's lack of appreciation for human rights considerations. ${ }^{91}$

on personal violence, as it is more apparent; this perception is rooted in the Judaeo, Christian, Roman traditions. See Galtung, at 173.

85 See Christopher Kutz, Complicity: Ethics and Law for a Collective Age 188 (2000) [hereinafter Kutz]; John Elster, Marxism, functionalism, and game theory: The case for methodological individualism, 11 Theory \& Soc'y 453 (1982).

86 In her discussion of the dynamics governing social structural processes, Young contrasts methodological individualism's understanding of direct relations to the view that social structural processes exist and are produced only in action. See Young (2011), at 59-62.

87 See Kutz, at $3-6$.

88 See Ulrich Beck \& Elisabeth Beck-Gernsheim, Individualization: Institutionalized Individualism and its Social and Political Consequences xxi (2001); Susan Marks, State-Centrism, International Law, and the Anxieties of Influence, 19 Leiden J. Int'l L. 339 (2006). International Law upholds the liberal statist position whereby states are subject and sources of international law. See A. Claire Cutler, Private Power and Global Authority: Transnational Merchant Law in the Global Political Economy 21 (2003) [hereinafter Cutler]. See also, generally, Andreas Wimmer \& Nina Glick Schiller, Methodological Nationalism, the Social Sciences, and the Study of Migration: An Essay in Historical Epistemology, 37 Int'l Migration Rev. 576 (2003); Young, at 135.

89 See Cutler, at 26-27.

9 See id., at $57-58$.

91 See Barnali Choudhury, International Investment Law and Non-Economic Issues, 50 Vanderbilt J. Transnat'l L. 1 (2020); Monica Feria-Tinta, Like Oil and Water? Human Rights in Investment Arbitration in the Wake of Philip Morris v. Uruguay, 34 J. Int'l Arb. 601 (2017). 
In this context, ARISWA's focus on "violations" instead of "harm" goes hand in hand with a juridical mindset that conceptualizes responsibility as one arising out of direct interpersonal relations and within the confines of national borders and separated from economic considerations. The joint effect of these three elements undermines the ability of international law to capture and remedy systemic economic harm. Nonetheless, there exists a number of frameworks (especially those not transposed from national law) which escape such theoretical limitations, perhaps offering unusual remedial paths. Such frameworks are discussed in the following part.

\section{Alternative Paths of Redress for Systemic Economic Harm under Occupation}

At this juncture, the paper will refocus the attention from the general question of responsibility for systemic economic harm, to investigating alternative forms of redress for systemic economic harm, as imagined in relation to the social connections model. In this respect, the Basic Principles and Guidelines on the Right to a Remedy and Reparation for Victims of Gross Violations of International Human Rights Law and Serious Violations of International Humanitarian Law define victims as: "persons who individually or collectively suffered harm, including physical or mental injury ... economic loss ... through acts or omissions that constitute gross violations of international human rights law, or serious violations of international humanitarian law." ${ }^{92}$ Once identified as such, the victim has the right to: equal and effective access to justice; adequate, effective and prompt reparation for harm suffered; and access to relevant information concerning violations and reparation mechanisms. ${ }^{93}$

Under this definition, we can say that people suffering from economic loss prompted by blanket violations of international law are victims who deserve redress. Once again, the traditional framework of responsibility provides little aid as, international law lacks the procedura' )acity to juridically offer redress $t$ a systemic harm prompted by a given suc. ${ }^{94}$ This absence calls for the pursuic of alternative paths. This section investigates such paths. To do so, it looks at frameworks that invite some forms of redress from two other agents with the power and privilege to affect the structure causing the systemic harm: the corporate actor and third states.

\footnotetext{
92 U.N. Doc. A/RES/6o/147 (Mar. 21, 2006), at V (emphasis added).

93 Id., at VII.

94 See Dinah Shelton, Remedies in International Human Rights Law 7 (3rd ed., 2015).
} 
A Systemic Economic Harm and the Business and Human

\section{Rights Framework}

Corporations, as the main engine of capital accumulation, ${ }^{95}$ have considerable power and privilege in local economies. ${ }^{96}$ In light of this positioning, the social connections model would impose social duties on the corporate actor. Nevertheless, traditional corporate governance d as not often account for such a duty. This absence creates a "governance $g$ " in relation to transnational human rights. ${ }^{97}$ This gap means that few legal constraints exist to contain the risk of the involvement of business enterprises in exploitative relations which generate systemic economic harm in conflict areas. ${ }^{98}$ Consequently, little use was made of the power of corporations to influence systems sustaining structural injustice.

This gap is rooted in the fact that corporations are not formally subjects of international law. ${ }^{99}$ Formal legal mechanisms of accountability such as the Rome Statute of the International Criminal Court do not reference corporations, despite the fact that the drafters considered such inclusion. ${ }^{100}$ Exceptionally, some human rights instruments leave a space for interpretation, under which some obligations can be extended to corporations. ${ }^{101}$ There are also mechanisms of accountability which reference corporate accountability such as the work of the International Law Commission on the liability of legal

95 See Bastiaan Van Apeldoorn \& Nana de Graaff, The Corporation in Political Science, in The Corporation: A Critical Multi-disciplinary handbook 134, 135 (Grietje Baars \& Andrew Spicer eds., 2017).

96 See Ulrich Beck, Power in the Global Age: A New Global Political Economy 52-55 (2014).

97 See Beate Sjåfjell \& Mark B. Taylor, Clash of Norms: Shareholder Primacy vs. Sustainable Corporate Purpose (2019) [hereinafter Sjåfjell \& Taylor], https://papers.ssrn.com/ abstract $=344405^{\circ}$.

98 See Hugo Slim, Business actors in armed conflict: towards a new humanitarian agenda, 94 Int'l Rev. Red. Cross 903 (2012).

99 "They - Corporations-remain entities created by the national law of their place of incorporation." Brief of Amicus Curiae Professor James Crawford in Support of Conditional Cross-Petitioner, Presbyterian Church of Sudan et al. v. Talisman Energy Inc., No. o9-1418 (Jun. 23, 2010), at 11.

100 In the course of drafting the Rome Statute, suggestions to include reference to corporate personality in the ethos of the case law of the industrialists' trials in Nuremberg were overruled. See, generally, Michael J. Kelly, Prosecuting Corporations for Genocide (2016).

101 An explicit account of such extended obligations is found in: David Weissbrodt \& Muria Kruger, Norms on the Responsibilities of Transnational Corporations and Other Business Enterprises with Regard to Human Rights, 97 Am. J. Int'l L. 901 (2003). 
persons for crimes against humanity, ${ }^{102}$ the Special Tribunal for Lebanon, ${ }^{103}$ and the Malabo Protocol. ${ }^{104}$

Different attempts to draft international legal instruments that consider the corporate actor a responsible social actor, who can support the interests of the local community, failed to gain sufficient support. One notable attempt in the 1970s sought to address Global South states' dismay with transnational corporations' negative impact on their local economies. ${ }^{105}$ A draft proposed a code of conduct for transnational corporations as a binding international instrument that would impose on corporations a social role. ${ }^{106}$ The drafts of the proposed code (the last version of which was published by the UN Centre for Transnational Corporations in 1988), can be read as a counter-narrative to the traditional understanding of causality entrenched in methodological individualism and nationalism.

Adopting a developmental rhetoric, enshrined in an appeal to the interdependent nature of the global economy, the proposed code imposed direct international obligations on corporations to respect public considerations like responsible engagement with the local economy in a manner that would avoid

102 "There are several treaties that address the liability of legal persons for criminal offences, notably: the 1973 International Convention on the Suppression and Punishment of the Crime of Apartheid; the 1989 Basel Convention on the Control of Transboundary Movements of Hazardous Wastes and Their Disposal; the 1999 International Convention for the Suppression of the Financing of Terrorism; the 2000 United Nations Convention against Transnational Organized Crime; the 2000 Optional Protocol to the Convention on the Rights of the Child on the sale of children, child prostitution and child pornography; the 2003 United Nations Convention against Corruption; the Protocol of 2005 to the Protocol for the Suppression of Unlawful Acts Against the Safety of Fixed Platforms Located on the Continental Shelf; and a series of treaties concluded within the Council of Europe. Other regional instruments address the issue as well, mostly in the context of corruption." U.N. I.L.C., Report of the International Law Commission, 71st session (29 April-7 June and 8 July-9 August 2019), U.N. Doc. A/74/10 (2019), at 82-83.

103 In the cases of New TV S.A.L. and Akhbar Beirut S.A.L., the Special Tribunal for Lebanon decided to hold corporate legal persons liable for the crime of contempt. See Nadia Bernaz, Corporate Criminal Liability under International Law: The New TV S.A.L. and Akhbar Beirut S.A.L. Cases at the Special Tribunal for Lebanon, 13 J. Int'l Crim. Just. 313 (2015).

104 Protocol on Amendments to the Protocol on the Statute of the African Court of Justice and Human Rights, June 27, 2014. Annex article 1 (3).

105 See Center for Transnational Corporations, Transnational Corporations: Issues Involved in the Formulation of a Code of Conduct, U.N. Doc. E/C.10/17 (July 20, 1976) [hereinafter CTC Code of Conduct]. See also Karl P. Sauvant, The Negotiations of the United Nations Code of Conduct on Transnational Corporations: Experience and Lessons Learned, 16 J. World Inv. \& Trade 11 (2015).

106 See CTC Code of Conduct. 
direct and systemic harm. ${ }^{107}$ The code also took account of the asymmetrical relation between Global South states and foreign investors from developed states, by instating clauses about technology transfers and the renegotiation of investment agreements in good faith. ${ }^{108}$

Had party members accepted the proposed UN Code of Conduct, a corporation operating in the occupied Palestinian territories would have had a positive obligation to adhere to the local community's economic goals, development objectives, and socio-cultural objectives. ${ }^{109}$ In addition, it would have required the corporation to contribute to the Palestinian economy's well-being by, for instance, making investment decisions which support the diversification of Palestinian exports. ${ }^{110}$ The proposed code would have empowered the relevant national courts to enforce these obligations, and would have established an international institutional mechanism to monitor this enforcement. ${ }^{111}$

Other attempts followed the 1988 proposed code. ${ }^{112}$ The most recent and successful of these is the United Nations Guiding Principles on Business and Human Rights (UNGPs), endorsed unanimously by the UN Human Rights Council in 2011. ${ }^{113}$ The UNGPs put forth a framework rooted in: (1) the corporation's duty to respect human rights; (2) the state's duty to protect from human rights infringement; and (3) the victim's right to remedy. UNGP Principle 7 addresses the situation of "conflict affected areas" placing a higher level of responsibility on the home state and neighboring states. ${ }^{114}$ This stance presumes that the host state, in which corporate activity takes place, lacks effective control over its own territories at the time of war. This is the case of Palestine, which considerably lacks control over foreign corporations operating within its territories. In this context, the UNGPs require home states

107 See United Nations Centre for Transnational Corporations, The United Nations Code of Conduct on Transnational Corporations U.N. Doc. ST/CTC/SER.A/4 (1988) paras. 9-16 [hereinafter CTC Code of Conduct].

108 CTC Code of Conduct, paras. 11, 28-29, 36.

109 Id., at paras. 9, 12 .

$110 \quad I d$., at 14.

111 Id., at $22-26$.

112 U.N. ECOSOC, Norms on the responsibilities of transnational corporations and other business enterprises with regard to human rights, U.N. Doc. E/CN.4/Sub.2/2003/12/Rev.2 (Aug. 26, 2003), pmbl.

113 See H.R.C., Guiding Principles on Business and Human Rights: Implementing the United Nations "Protect, Respect and Remedy" Framework, A/HRC/17/31 (2011); U.N. OHCHR, Guiding Principles on Business and Human Rights: Implementing the 'Protect, Respect and Remedy framework,' HR/PUB/11/O4 (2011) [hereinafter UNGPs].

114 "Because the risk of gross human rights abuses is heightened in conflict affected areas, States should help ensure that business enterprises operating in those contexts are not involved with such abuses, including by: ... etc." UNGPs, Principle 7. 
where the corporation is incorporated to help corporations "identify, prevent and mitigate the human rights-related risks of their activities and business relationships."115

This identification of risk is relevant to an important mechanism that the UNGPs endorse, and that is the conjuring of due diligence reports within the context of corporations' responsibility to protect. ${ }^{116}$ This mechanism is originally found in legal tools that states have already been using to ensure corporations' responsible behavior with respect to other topics, including situations of war. ${ }^{117}$

Due diligence reporting in the realm of business and human rights denotes, among other things: an obligation to identify, mitigate, and prevent the human rights risks that are related to corporate activities. The obligation is general to all situations, ${ }^{118}$ and is heightened in the context of war. ${ }^{119}$ This heightened duty can be understood to widen the scope of consideration to include an assessment of systemic forms of harm. Despite the framework's exclusive focus on the language of human rights, its postulation of due diligence as a

115 UNGPs, Principle 7(a).

116 See the Human Rights Due Diligence (HRDD) Project, which was launched by the International Corporate Accountability Roundtable (ICAR), the European Coalition for Corporate Justice (ECCJ), and the Canadian Network on Corporate Accountability (CNCA): Human Rights Due Diligence Project, Coalition for Human Rights in Development, https://rightsindevelopment.org/human-rights-due-diligence-project/.

117 See, e.g., Section 1502 of the Dodd-Frank Wall Street Reform and Consumer Protection Act which requires companies with securities registered with the Securities and Exchange Commission to report on their due diligence with respect to conflict minerals to address corporate complicity in resource war of the DRC; later endorsed by the OECD's "Due Diligence Guidance for Responsible Supply Chains of Minerals from Conflict-Affected and High-Risk Areas." Olivier De Schutter, Anita Ramasastry, Mark B. Taylor, Robert C. Thompson, Human Rights Due Diligence: The Role of States (Dec. 2012), at 46, 84, https://en.frankbold.org/sites/default/files/publikace/human_rights_due_diligence-the _role_of_states.pdf.

118 According to the UNGPs Reporting Framework, human rights due diligence is: "An ongoing risk management process ... in order to identify, prevent, mitigate and account for how [a company] addresses its adverse human rights impacts. It includes four key steps: assessing actual and potential human rights impacts; integrating and acting on the findings; tracking responses; and communicating about how impacts are addressed." See: https://www.ungpreporting.org/wp-content/uploads/UNGPReportingFramework_2017 .pdf.

119 UNGPs, Principle 7, commentary ("States should warn business enterprises of the heightened risk of being involved with gross abuses of human rights in conflict-affected areas. They should review whether their policies, legislation, regulations and enforcement measures effectively address this heightened risk, including through provisions for human rights due diligence by business".). 
preventive mechanism necessitates stretching the analysis over a wider temporal and spatial frame of consideration. Such frame can capture the indirect harms that daily economic activities generate, such as utilizing water resources extracted in contravention to the rules of usufruct.

Once identified, such risks become ingrained within the corporate duty of care and it has a duty to mitigate such adverse effects. ${ }^{120}$ If such risks were to occur, victims ought to have recourse to national tort adjudication, or nonjudicial grievance mechanisms that the state or the corporation provides. ${ }^{121}$ Setting this standard for transnational businesses indirectly encourages states to ensure that their legal systems and economic policies do not permit indirect involvement in human rights violations for corporations.

As suggested by their title, adherence to the UNGPs is voluntary. ${ }^{122}$ Voluntarism denotes that a given standard is favorable but not obligatory. For some scholars, voluntarism allows for the application of incentivizing tools which promote responsible corporate behavior in a dynamic fashion. ${ }^{123}$ Meanwhile, others argue that the absence of stringent legal standards, ${ }^{124}$ promotes a culture where corporations are allowed to do minimal efforts while avoiding structural changes in their behavior towards communities. ${ }^{125}$ Yet such voluntarism does not concretely break away with the entrapment in a paradoxical situation that Young identified. This is because it is not in the interest of the corporation to cut profits for the sake of local communities. Such a hurdle might be overcome through the recently proposed mandatory due diligence framework in the European Union, or if the initiative of a binding treaty on business and human rights were to succeed. ${ }^{126}$

\footnotetext{
120 UNGPs, Principle 13(b).

121 UNGPs, part 3.

122 See Steven Bittle \& Laureen Snider, Examining the Ruggie Report: Can Voluntary Guidelines Tame Global Capitalism? 21 Critical Criminology 177 (2013); Beate Sjåfjell, Why Law Matters: Corporate Social Irresponsibility and the Futility of Voluntary Climate Change Mitigation (2011), https://papers.ssrn.com/abstract=1774759.

123 See John J. Kirton \& M. J. Trebilcock, Hard Choices, Soft Law: Voluntary Standards in Global Trade, Environment, and Social Governance (2004).

124 See Sjåfjell \& Taylor; Björn Fasterling \& Geert Demuijnck, Human Rights in the Void? Due Diligence in the UN Guiding Principles on Business and Human Rights, 116 J. Bus. Ethics 799 (2013).

125 See Upendra Baxi, Towards socially sustainable globalization: reflections on responsible contracting and the UN guiding principles on business and human rights, 57 Indian J. Int'l L. 163 (2017).

126 See European Coalition for Corporate Justice, Commissioner Reynders announces EU corporate due diligence legislation (Apr. 30, 2020), https://corporatejustice.org/news/168o6 -commissioner-reynders-announces-eu-corporate-due-diligence-legislation.
} 
In 2014, the UN Human Rights Council initiated another attempt to draft a binding treaty through the establishment of an open-ended intergovernmental working group on transnational corporations and other business enterprises with respect to human rights. ${ }^{127}$ The group's main mandate is to oversee the drafting of a binding treaty "to regulate, in international human rights law, the activities of transnational corporations and other business enterprises." 128 Thus far, the working group has presented a number of drafts for a binding treaty. The most recent (at the time of writing) focuses predominantly on access to justice for victims, ${ }^{129}$ criminal and civil liability with reference to crimes under the Rome Statute, ${ }^{130}$ and prevention mechanisms solidifying the duty of corporate human rights due diligence. ${ }^{131}$ The draft also requires that such human rights considerations are taken into account in future business relations and that current contracts are interpreted in line with the obligation to respect human rights. ${ }^{132}$

While restrictive in scope, keeping a distance from economic considerations, ${ }^{133}$ the treaty would nonetheless crystallize the notion of corporate due diligence allowing for wider consideration of systemic forms of harms. This would indirectly shift corporate attitude towards becoming a more active actor in reforming policies which incite systemic economic harm. Despite upholding a state-centric perspective, the draft stresses internal civil and criminal accountability mechanisms reliant on the scope of duty of care set in the due diligence framework opening new remedial pathways that focus on non-state actors with power and privilege and collective ability. It further sets a juridical basis for extraterritorial jurisdiction, under which victims can prosecute corporations in their home states. The absence of such jurisdiction, linked

127 See Pierre Thielbörger \& Tobias Ackermann, A Treaty on Enforcing Human Rights Against Business: Closing the Loophole or Getting Stuck in a Loop?, 24 Ind. J. Glob Leg. Stud. 43 (2017).

128 H.R.C., Elaboration of an international legally binding instrument on transnational corporations and other business enterprises with respect to human rights, U.N. Doc. A/HRC/ RES/26/9 (July 14, 2014), para. 1.

129 OEIGWG Chairmanship, Legally binding instrument to regulate, international human rights law, the activities of transnational corporations and other business enterprises (Rev. draft, July 16, 2019), art. 4 [hereinafter OEIGWG Revised Draft], https://www.ohchr.org/ Documents/HRBodies/HRCouncil/WGTransCorp/OEIGWG_RevisedDraft_LBI.pdf.

$130 \quad$ Id., art. 6.

131 Id., art. 5 .

132 Id., art. 12.

133 The discussion over the draft had included requests to include references to corporate capture and development. See H.R.C., Report on the fifth session of the open-ended intergovernmental working group on transnational corporations and other business enterprises with respect to human rights, U.N. Doc. A/HRC/43/55 (Jan. 9, 2O2O), paras. 13, 67 . 
with an appeal to methodological nationalism which denies the trans-border nature of corporate activity, has been one of the dominant reasons for the impunity of corporate actors. ${ }^{134}$ Such mechanisms can indirectly function to change state-investor dynamics. States wishing to attract investment will have to provide a better environment for investment where the corporate actor will not easily find themselves connected to human rights and humanitarian violations. It thus would indirectly pressure states to address some forms of structural injustice.

In the context of the Israeli occupation, the ethos of the UNGPs paid particular attention to the role of corporations as active actors with power and privilege. The UN Human Rights Council initiated this discussion in the aftermath of UN Security Council Resolution 31/36, which condemned Israeli settlements built in occupied Palestine. ${ }^{135}$ The Resolution requested the office of the UN High Commissioner for Human Rights (OHCHR) to prepare a report on the implications of the issue. ${ }^{136}$ Eventually, this led to the creation of the UN database on business enterprises involved in Israeli settlements. The database is seen as a transparency tool to guide later assessments. ${ }^{137}$

In the preliminary report on the UN database, ${ }^{138}$ the Office of the High Commissioner for Human Rights determined that economic actors investing in the settlements are benefitting from policies that produce systemic economic harm. For example, corporations benefit from access to surplus cheap labor that the systematic illegality of the settlements breeds, exploitation of contested resources, and from Israeli investment policies. ${ }^{139}$ Hence, corporations' involvement indirectly enables the deterioration of the Palestinian

134 See Nadia Bernaz, Enhancing Corporate Accountability for Human Rights Violations: Is Extraterritoriality the Magic Potion? 117 J. Bus. Ethics 493 (2013).

135 H.R.C., Israeli settlements in the Occupied Palestinian Territory, including East Jerusalem, and in the occupied Syrian Golan, U.N. Doc. A/HRC/RES/31/36 (Mar. 24, 2016), para. 17.

${ }_{13} 6$ The issue had been presented in a prior report. H.R.C., Report of the independent international fact finding mission to investigate the implications of the Israeli settlements on the civil, political, economic, social and cultural rights of the Palestinian people throughout the Occupied Palestinian Territory, including East Jerusalem, U.N. Doc. A/HRC/22/63 (Feb. 7, 2013).

137 See H.R.C., Database of all business enterprises involved in the activities detailed in paragraph 96 of the report of the independent international fact-finding mission to investigate the implications of the Israeli settlements on the civil, political, economic, social and cultural rights of the Palestinian people throughout the Occupied Palestinian Territory, including East Jerusalem - Report of the United Nations High Commissioner for Human Rights, U.N. Doc. A/HRC/37/39 (Feb. 1, 2018), para. 9.

138 See id.

139 Id., paras. $43^{-45}$. 
economy. ${ }^{140}$ Additionally, the report points out that corporations benefit from filling the space that Israeli policies create and which render Palestinians incapable of exploiting their own oil and gas among other natural resources. ${ }^{141}$ The importance of the database and its novelty lie in the fact that it relies on the business and human rights framework in its assessment. Thus, the database is able to capture different forms of systemic economic harms. This is achieved by linking between, on the one hand, the deterioration of the Palestinian economy and, on the other hand, Israeli policies and business enterprises.

The discussion of these previous attempts (the 1988 proposed code, UNGPs, 2014 attempt to draft a treaty, and the UN database) showcases the availability of alternative frameworks that can provide some form of redress for different forms of structural injustice through imposing obligations on the corporate actor. If adopted and enforced, such mechanisms are likely to directly impact the corporation's participation in economic systems, and to indirectly encourage states to deter policies that may induce systemic economic harm.

In this respect, human rights due diligence frameworks offer a window of hope where indirect causality can be imagined and further integrated in responsibility frameworks, opening new remedial paths for victims. In such frameworks, corporations that benefit from or contribute to structural forms of injustice that originate in violations of international law can be held accountable. They can be incentivized to use their leverage to demand a fairer economic environment. However, voluntarism and the marginalization of economic considerations limit the capacities of these new mechanisms to lead to profound changes in an occupation's policies. Nonetheless, this framework can be complemented with another framework designed to call upon the leverage of third states discussed in the next section.

\section{B Third States and Systemic Harm in Occupation}

Third states are connected to the occupation's apparatus by virtue of global economic and political interdependence. Like other actors, their role in the connections upholding a given structural injustice varies according to their own power, leverage, interest, and collective ability. To begin with, as states theoretically have leverage over corporations incorporated under their own jurisdiction, they can practice their influence to deter corporations from undertaking activities which contribute to or benefit from an apparatus sustaining systemic economic harm. To this end, the UNGPs place a responsibility on states "where they fail to take appropriate steps to prevent, investigate,

\footnotetext{
140 Id., paras. $47,54$.

141 Id., paras. $43^{-45}$
} 
punish and redress private actors' abuse,"142 and the proposed draft aims to solidify this obligation. ${ }^{143}$ Likewise, under the ARISWA framework, there are limited cases where states can be held responsible for the conduct of business enterprises acting in governmental authority. ${ }^{144}$

For the purpose of remedying systemic harm, one particular duty set out in ARISWA, provides an interesting perspective which speaks to the thinking behind the social connections model, and that is the third state's positive duty to cooperate and its negative duty of non-recognition in the face of a given serious violation of international law. ${ }^{145}$ The term "serious breach" denotes breaches of the peremptory norms of international law, in particular the prohibition against apartheid and violations of the peoples' right to self-determination. ${ }^{146}$ Such seriousness is also assessed in terms of "a gross or systematic failure by the responsible state to fulfil the obligation in question."147 The UN repeatedly stressed such duties of third states in relation to occupied Palestine, specifically in the context of Israeli settlements, as in UN Security Council Resolution $465 .{ }^{148}$ Similarly, Resolution 2334 establishes a duty on third states "not to provide assistance" to activities undertaken to sustain or build settlements. ${ }^{149}$

This duty articulates how the interconnected positioning of the economy of other states to the Israeli economy grants third states power and privilege with regards to the dynamics sustaining systemic economic harm. It thus requires non-recognition of the effects born out Israeli violations of international law, and consequently imposes responsibility on third states to withhold different forms of cooperation which can sustain or contribute to ongoing violations of international law.

The implementation of these principles of third states' responsibility in relation to the context settlement activity generates a lively scholarly debate. At one end, there is Moernhout's intervention, which is premised on the illegality settlement activity. ${ }^{150}$ His assessment adopts a systematic view that

142 "States may breach their international human rights law obligations where such abuse can be attributed to them, or where they fail to take appropriate steps to prevent, investigate, punish, and redress private actors' abuse." See UNGPs, Principle 1, commentary.

143 See OEIGWG Revised Draft.

144 See, generally, ARSIWA.

145 See ARSIWA Commentaries, at 31, 112-116, art. 41.

146 See id., art. 40, at 112-113.

147 See id.

148 S.C. Res. 465 (Mar. 1, 1980).

149 S.C. Res. 2334 (Dec. 23, 2016).

150 Tom Moerenhout, The Obligation to Withhold from Trading in Order Not to Recognize and Assist Settlements and Their Economic Activity in Occupied Territories, 3 J. Int'l Human. Legal. Stud. 344 (2012) [hereinafter Moerenhout]. 
looks at the effects of the spatial and temporal stretch of the settlements and determines that the illegal nature of the context deems economic activities by third states in the settlements altogether illegal. He concludes that this illegality imposes an obligation on third states to withhold trade with the settlements in adherence to the duty of non-recognition, as well as an obligation to prohibit multi-national corporations under their jurisdiction from undertaking such activities. ${ }^{151}$

In reply to Moernhout's position, it can be argued that this determination of state responsibility contradicts non-discrimination clauses in the General Agreement on Tariffs and Trade (GATT) under the regime of the World Trade Organization (WTO). This is because the act of halting economic activities can be portrayed as a disruption of the flow of free trade. Such a position would presume that the GATT is applicable in occupied Palestine. However, Palestine is a not a member of the WTO. Application of the GATT to its territory can only be understood as an extension of Israeli jurisdiction by virtue of its occupation. Such an extension can only be possible if one relies on an interpretation that deems occupied territories a part of the occupying state's territory. Under this interpretation, the occupying power would have the authority to decide whether or not to include the occupied territories under the regime of the GATT. Nonetheless, the only evidence to support this interpretation is weak. It is found in the travaux préparatoires of the GATT in 1957, where the suggestion to include an exclusion of occupied territories was dismissed, which could arguably insinuate that they are included under the jurisdiction of the occupying power. ${ }^{152}$

In response to this interpretation, Moerenhout argues that even if the GATT were to apply to the Palestinian territories, a harmonized reading of international law as a self-contained system would consider the duty of non-recognition as possessing a humanitarian appeal which warrants an exception to the non-discrimination rule. ${ }^{153}$ Several scholars advocate for this

151 Id., at $354-361$.

$15^{2}$ This argument is based on interpretive notes to Article XXVI: 5 (b) of the GATT "Until the Review Session amendments agreed in 1954-55, an interpretative note to Article XXVI provided that "Territories for which the contracting parties have international responsibility do not include areas under military occupation." A Final Note provided that "The applicability of the General Agreement on Tariffs and Trade to the trade of contracting parties with the areas under military occupation has not been dealt with and is reserved for further study at an early date. Meanwhile, nothing in this Agreement shall be taken to prejudge the issues involved. This, of course, does not affect the applicability of the provisions of Articles XXII and XXIII to matters arising from such trade". These provisions were deleted effective October 7, 1957. See W.T.O. Analytical Index of the GATT (1994), https://www.wto.org/english/res_e/publications_e/ai17_e/gatt1994_art26_gatt47.pdf.

153 See Moerenhout, at 376-377. 
harmonized reading because they maintain that the absence of unity in reading international law emits inconsistencies and collisions in practice. ${ }^{154}$

Advocates for a harmonized reading of international law argue that harmony is an essential element for coherence and legitimacy. Among those advocating for a harmonized reading of international law is the former president of the International Court of Justice Stephen Shewebel, who expresses his dissatisfaction with fragmentation of international law, when he argues that it fosters further confusion and threatens the legitimacy of international law. As a remedy, he proposes a unification scheme that starts with allowing all courts to refer cases to the International Court of Justice. ${ }^{155}$ In contrast, the International Law Commission's draft articles on the fragmentation of international law provide a formalistic middle way that promotes acceptance of the current fragmented state but pushes for some elements of harmonization. ${ }^{156}$

From the perspective of Young's connections model, which this article adopts, a fragmented reading of international law further distorts the law's perception, as it deepens the exclusion of economic considerations from the public sphere and obstructs a proper understanding of causality. In the case of third states' obligation not to recognize serious breaches of international law, prioritizing the free trade rhetoric insinuates a disregard of serious breaches by the international community. Additionally, this fragmentation encourages a multiplicity in legal analyses of global issues, each time under the language of a different code without an effort to establish a more holistic understanding that bears the fruit of addressing structural injustice.

Another mechanism, reliant on the will of third states, which captures connections that affect a given dominating apparatus, is that of multilateral or unilateral economic sanctions. Economic sanctions utilize economic privilege of third states to pressure a given state into abiding by international law. With relation to affecting the apparatus upholding systemic economic harm in occupation, national jurisdictions and international instruments are reluctant to criminalize or prohibit economic dealings with occupying states and occupied territories, even in cases of systematic breach of international law as is the case with the settlements.

\footnotetext{
154 "Contemporary international law is torn between opposing dichotomies, competing languages, and uncovered subjectivities." Sahib Singh, The Potential of International Law: Fragmentation and Ethics, 24 Leiden J. Int'l L. 23 (2011).

155 See Address to the Plenary Session of the General Assembly of the United Nations by Judge Stephen M. Schwebel, President of the International Court of Justice (Oct. 26, 1999).

156 See, generally, I.L.C., Conclusions of the work of the Study Group on the Fragmentation of International Law: Difficulties arising from the Diversification and Expansion of International Law, in U.N. Doc. A/61/10 (2006).
} 
Lastly, other softer mechanisms put forth by third states with the aim of deterring trade to affect Israeli policies include anti-normalization laws against Israeli occupation that used to exist in the Arab region but heavy US diplomacy thwarted such measures (similar to those legislated against the South African apartheid regime), ${ }^{157}$ the European Commission's “Interpretative Notice on the Indication of Origin of Goods from the Territories Occupied by Israel since June 1967,"158 and the European Court of Justice's judgement on the labelling of products coming from Israeli settlements. ${ }^{159}$

\section{Concluding Remarks}

Applying the perspective of the social connections model to the reality of occupation, it is apparent that the effects of Israeli policies as an occupying power have a structural effect on the individual and collective capacity of Palestinians to pursue economic development. Many of these policies, which are intertwined with blanket violations of international law, eventually deepen the dependence and fragility of the Palestinian economy and cripple its capacity to develop and to undertake competitive economic activities globally. Israeli policies, therefore, cause systemic economic harm.

It is difficult to conceptualize legal redress for such forms of systemic harm in legal systems that understand and frame responsibility with relevance to direct relationships within nation states, rather than networked relations of a transnational nature. This difficulty is exacerbated in relation to economic harm as it is harder to conceptualize and is historically marginalized under the premise of the private-public distinction. Thus, even if blanket violations committed by the occupation were to be condemned, current responsibility frameworks are still inadequate because they do not account for casual links between systemic economic harm and the violations committed. Ways around this substantive shortcoming are found in alternative paths which focus on the responsibility of other actors with power, privilege and collective ability such as corporations and third states.

The argument in support of providing a remedy for structural injustice through engraining a social role for corporate actors has been present in the

\footnotetext{
157 These laws are an in enactment of the Arab league's boycott of Israel, however most of its clauses are dormant. Andre M. Saltoun, Regulation of Foreign Boycotts, 33 Business Lawyer 559-6o3 (1978).

$15^{8}$ Interpretative Notice on Indication of Origin of Goods from the Territories Occupied by Israel Since June 1967, 2015 O.J. (C 375).

159 C-363/18, Vignoble Psagot Ltd v. Ministre de L'Economie et des Finances, 2019 E.C.R. 954.
} 
halls of the UN since early seventies. Nonetheless, attempts to assign direct responsibility to corporations have met little success thus far. One positive development has been the establishment of a discourse around a duty of human rights due diligence for corporate actors, and which is considered a heightened duty in conflict-affected areas. Such due diligence requirement allows the assessor to stretch their gaze over a longer temporal and spatial span. This in turn paves the way for an appreciation of systemic harm that corporate activity induces, whether directly or through apparatuses from which it benefits, or to which it contributes. Although the voluntary nature of this duty remains its biggest weakness, it nevertheless had considerable political value in triggering the publication of the UN database on corporations involved in Israeli settlements. Despite being in its early stages, the database has already steered the discussion towards a more inclusive understanding of causality, particularly with respect to the context of settlements.

Finally, another route to provide for redress for systemic economic harm is through the enactment of third states' duty not to recognize the facts created by severe violations of international law. Tho application of this duty would foreground a more egalitarian economic $\mathrm{f} \overline{\bar{n}} \mathrm{ng}$ between the Palestinians and Israel. Yet, in order to enable the application of this duty one needs to overcome a fragmented reading of international law whereby the practice of such non-recognition would contravene the duty of non-discrimination under the GATT C.ch a fragmented reading further deepens international law's substantive s] $=$ coming in relation to systemic harm and diminishes the right of the occupied population to seek economic development.

\section{Acknowledgments}

The author would like to thank Dr. Nimer Sultany for his vigilant revision, discussion, support and commentary, and Dr. Ralph Wilde whose support and courage inspired this paper. 